\title{
Pyocine typing of Pseudomonas aeruginosa
}

\author{
M. A. M. OSMAN
}

From the University Department of Bacteriology, Western Infirmary, Glasgow

SYNOPSIS The growth-inhibitory effect of a small group of different pyocines has been used to differentiate Ps. aeruginosa isolates. A method is described which can be carried out with ordinary media and is easy for routine application. One hundred and one isolates of Ps. aeruginosa were differentiated by four pyocines into 10 pyocine patterns.

Pseudomonas aeruginosa strains are frequently the source of trouble in hospitals, first because they may multiply or exist in the most unpropitious and unlikely environments, such as $1 \%$ Cetavlon solution, 'sterile' water, on corks of bottles, as well as in wounds and in the renal tract and bronchial tree. Secondly, they are frequently resistant to many antibiotics, rendering infections, especially the parenteral ones, hard to treat. It is therefore useful to be able to supplement good detective work with typing of the organism. Serological grouping depending on the recognition of several somatic and flagellar factors (Graber, Latta, Vogel, and Brame, 1961) makes such grouping laborious and time consuming. Phage typing is faced by the high percentage of untypable strains (Warner, 1950) and variation in the pattern (Sutter, Hurst, and Fennell, 1963). The successful use of typing Shigella sonnei by detecting the effect of their colicine production on certain indicators (Abbott and Shannon, 1958; Barrow and Ellis, 1962), and contrariwise typing unknown pathogenic strains of $E$. coli by their sensitivity to known colicines (Linton, 1960) suggested that similar substances, namely, pyocines, could be used to type Ps. aeruginosa. Jacob (1954), Hamon (1956), Holloway (1960), and Hamon, Véron, and Péron (1961) investigated this matter and suggested that pyocines should be further examined.

\section{METHODS}

MORPHOLOGICAL AND BIOCHEMICAL IDENTIFICATION OF PS. AERUGINOSA Typing with pyocines requires first of all identification of the organisms, since other Pseudomonas species are inhibited by them, e.g., Ps. fluorescens. Most strains of Ps. aeruginosa are easily distinguished from other bacterial species on primary isolation by their characteristic colonial morphology, their smell, and their production of green pigment.

Received for publication 16 June 1964.
The most important tests for diagnosing the Ps. aeruginosa are the following:-

1 Pyocyanin production: growth on $1 \%$ sodium citrate medium (Sellers, Wynne, and Graber, 1962) is a reliable method of promoting pigment by organisms which by other methods appear not to produce pigment.

2 Growth at $42^{\circ} \mathrm{C}$. in a water-bath and no growth at $5^{\circ} \mathrm{C}$.

3 The presence of a polar monoflagellum as shown by flagellar staining (Leifson, 1960).

4 A rapid oxidase positive test (15-30 seconds) using $\alpha$-naphthol and p-aminodimethylaniline oxalate reagent (Gaby and Hadley, 1957).

5 If no initial pigment is produced then growth on Hugh and Leifson medium (Hugh and Leifson, 1953) should be used to differentiate Ps. aeruginosa species by the production of oxidative reaction from other genera like Aeromonas, Alcaligenes, and Achromobacter. If the growth on Hugh and Leifson medium results in an oxidative reaction the organism is regarded as Pseudomonas, and pyocyanin production is encouraged by growth of the bacteria on citrate medium.

The criteria 1, 2, 3, and 4 (and 5 when necessary) will differentiate species of Pseudomonas such as Ps. fluoroscens, Ps. putida, Ps. chlororaphis, and Ps. pseudomallei from Ps. aeruginosa.

PRODUCTION AND PRELIMINARY TESTING OF PYOCINES The term 'pyocine' is used to indicate the filtrates freed from bacteria by filtration through sintered filters and having inhibitory activity. The activity in the filtrate may be due to one or more pyocines. Fifteen ml. of nutrient broth contained in $100 \mathrm{ml}$. capacity screw-capped bottles is seeded with a Ps. aeruginosa culture and incubated at $37^{\circ} \mathrm{C}$. with gentle shaking for 24 hours. The culture is then centrifuged for 15 minutes to deposit most of the organisms and the supernatant broth passed through a sintered glass filter (average pore diameter of 1.05 to $1.25 \mu$ ). The sterile filtrate can be kept in a screw-capped bottle at $4^{\circ} \mathrm{C}$. for several months.

DIFFERENTIATION OF BACTERIOPHAGE FROM PYOCINE ACTION It is important to test the pyocine filtrate for the presence 
of bacteriophage and to establish that it is of sufficient potency. Decimal dilutions of the filtrate are therefore made in broth and tried against a large number of indicator strains of Ps. aeruginosa. If the activity of the filtrate is due to bacteriophage, the more diluted filtrates produce individual plaques of phage lysis. If inhibition zone appears without plaque formation it is assumed that pyocine activity is present. It should be noted that both may co-exist. It is preferable that the pyocine filtrates should be of such potency as to withstand appreciable dilution, e.g., 1 in 100 , without losing their inhibitory activity.

TECHNIQUE OF TYPING Six ml. of nutrient agar in a 3 inch Petri-dish is covered by a second layer of $3 \mathrm{ml}$. of semi-solid nutrient agar (0.67\% New Zealand agar), previously seeded at $40^{\circ} \mathrm{C}$. while liquid, with 2 drops $(0.04 \mathrm{ml}$.) of an overnight broth culture of the organism to be tested. The second layer is allowed to set and the plates are placed, partly covered, in an incubator to dry $\left(37^{\circ} \mathrm{C}\right.$. for 90 minutes). Drops of serial dilutions of pyocine filtrates are subsequently placed on the surface, and when they have dried in, the plates are incubated at $37^{\circ} \mathrm{C}$. overnight. Pyocine activity causes either clear punched-out zones of no growth or thinning of the growth around the site of application which may be due to dilution or in the case of an undiluted drop means a weak activity (Fig. 1). Occasional resistant colonies may be found in otherwise clear areas. It is necessary to prepare plates as described above to avoid the overgrowth of $P s$. aeruginosa which may otherwise mask the pyocine activity, especially when the latter is faint.

SOURCES OF CULTURES EXAMINED Pseudomonas aeruginosa cultures, 101 in number, were obtained from various

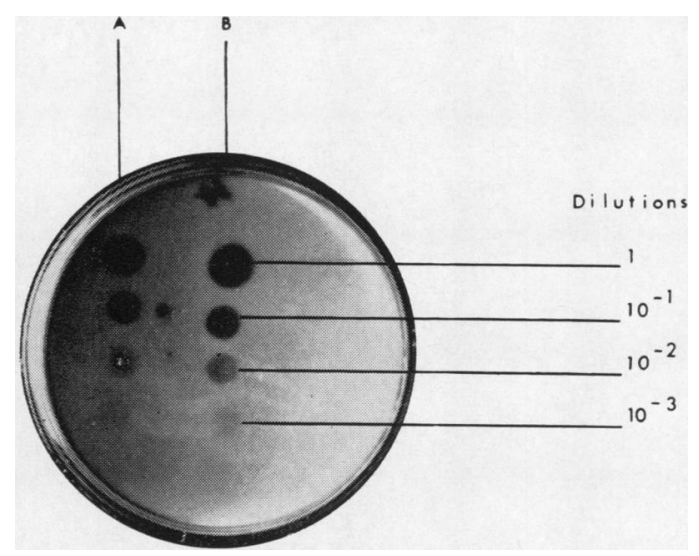

FIG. 1. Pyocine activity on a sensitive indicator $(\times 2 / 3)$. Decimal dilutions of two active pyocines are shown; undilute filtrates at the top, towards the bottom dilution increasing. The circular dark areas are transparent due to inhibition of growth. The areas become smaller as pyocine is diluted and then becomes gradually more opaque due to incomplete inhibition of the tested organism. Pyocine $A$ gives good inhibition at a dilution of $10^{-1}$ and pyocine $B$ at $10^{-2}$. sources-wounds, stools, urine, sputum, pus, ward bedding, and dust-from 10 different hospitals in the Glasgow area. The organisms were maintained on nutrient agar in screw-capped bijou bottles at room temperature $\left(21^{\circ} \mathrm{C}\right.$.) in the dark.

\section{RESULTS}

Filtrates from each of the 101 strains, prepared by the above method, were tested against the 101 Ps. aeruginosa parent cultures. By the method of setting up successive tenfold dilutions of all the filtrates in broth it was possible to differentiate inhibition zones caused by the pyocine from those caused by phages. Of the 101 filtrates, 99 exhibited a pyocine activity. Four different pyocines were chosen on the basis of specificity to classify the 101 cultures into 10 different pyocine patterns (Table I). The pyocines used in typing were given the numbers of their corresponding cultures $(96,46,8$, and 39). Pyocines 96,46 , and 8 were produced most probably from non-lysogenic cultures since their activities before and after filtration through ultrafilters $(10-20 \mathrm{~m} \mu)$ were almost identical. Pyocine 39 was from a lysogenic one since it showed plaques on one indicator. The presence of pyocine activity in this filtrate was proved by the demonstration of inhibition of another indicator strain even after ultrafiltration. It was unfortunate that pyocine 39 contained phage, and it was always necessary in the present tests to determine the nature of the inhibition produced. All four pyocines exhibited a strong inhibitory effect and they differed from each other in their host specificity and were obtained from four serologically different cultures. Table I shows the reaction of the 101 strains of $P$. aeruginosa to the four pyocines; 10 types can be distinguished.

\section{TABLE I}

CLASSIFICATION OF 101 ISOLATES ACCORDING TO THEIR PYOCINE PATTERN

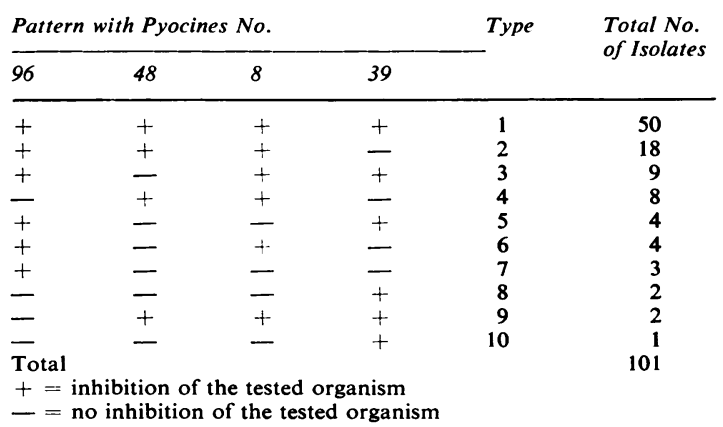

Examination of pyocine typing results showed that these were stable characteristics, of use in epidemiological work. Repeated cultures obtained from the 
same patients at 10-day intervals or different colonies from the same culture possessed identical pyocine patterns. Likewise, injection of and recovery from mice of different strains of Ps. aeruginosa did not alter either pyocine patterns or ability of the strain to produce pyocine. Repeated subculture had a similar lack of effect. On the other hand, pyocine types obtained from some hospitals predominated and were different from those of another hospital.

An arbitrary unit for each pyocine was defined as the highest dilution of the pyocine that caused a clear zone in the seeded soft agar containing the indicator. The dilutions of pyocines $96,46,8$, and 39 that gave clear inhibition zones of $13,11,11$, and $12 \mathrm{~mm}$. diameter respectively on the indicator 50 (for the pyocines 96,46 , and 8 ) and on the indicator 2 (for pyocine 39 ) were $1 / 100,1 / 100,1 / 100$, and $1 / 10$ respectively. The indicator lawn was inoculated by $10^{7}$ indicator cells (as estimated by Brown's opacity tubes) of a 17 hours' culture and incubated at $37^{\circ} \mathrm{C}$. for 18 hours.

Such an arbitrary unit is necessary because pyocines of high activity are of wider range in their inhibitory action than when diluted to a suitable titre.

\section{CONCLUSIONS}

Typing on the basis of pyocine sensitivity is both stable and reproducible. Furthermore, pyocines are not difficult to prepare and keep for long periods.
Efforts in this field in the future should be directed towards the isolation of pyocines from non-lysogenic $P s$. aeruginosa which possess different host specificities. This can only be done by trial and error, a standard battery of bacterial strains and corresponding pyocines being gradually accumulated on the basis of typing experience. Once the prepared pyocines are proved to be from non-lysogenic cultures, decimal dilution is not necessary in the typing technique, further simplifying the method.

I wish to express my deep thanks to Professor J. W. Howie and Professor R. G. White for allowing me to work in the department and for their constant encouragement. I should like to thank Mr. G. Kerr for taking the photograph and making the print.

\section{REFERENCES}

Abbott, J. D., and Shannon, R. (1958). J. clin. Path., 11, 71.

Barrow, G. I., and Ellis, C. (1962). Mth. Bull. Minist. Hlth Lab. Serv., $21,141$.

Gaby, W. L., and Hadley, C. (1957). J. Bact., 74, 356.

Graber, C. D., Latta, R., Vogel, E. H., and Brame, R. (1961). U.S. Army Surg. Res. Unit Rep., MEDEW-RS-3-61, 1-14.

Hamon, Y. (1956). Ann. Inst. Pasteur, 91, 82.

, Véron, M., and Péron, Y. (1961). Ibid., 101, 738.

Holloway, B. W. (1960). J. Path. Bact., 80, 448.

Hugh, R., and Leifson, E. (1953). J. Bact., 66, 24.

Jacob, F. (1954). Ann. Inst. Pasteur, 86, 149.

Leifson, E. (1960). Atlas of Bacterial Flagellation. Academic Press, New York and London.

Linton, K. B. (1960). J. clin. Path., 13, 168.

Sellers, W., Wynne, E. S., and Graber, C. D. (1962). School of Aerospace Medicine, USAF Aerospace Medical Center, Brooks Air Force Base, Texas (62-36).

Sutter, V. L., Hurst, V., and Fennell, J. (1963). J. Bact., 86, 1354.

Warner, P. T. J. C. P. (1950). Brit. J. exp. Path., 31, 242. 